Hydrol. Earth Syst. Sci. Discuss., 5, 1821-1862, 2008 www.hydrol-earth-syst-sci-discuss.net/5/1821/2008/

(C) Author(s) 2008. This work is distributed under the Creative Commons Attribution 3.0 License.
Hydrology and

Earth System

Sciences

Discussions

Papers published in Hydrology and Earth System Sciences Discussions are under open-access review for the journal Hydrology and Earth System Sciences

\title{
A multi-objective optimization tool for the selection and placement of BMPs for pesticide control
}

\section{Maringanti ${ }^{1}$, I. Chaubey ${ }^{2}$, M. Arabi $^{3}$, and B. Engel ${ }^{4}$}

${ }^{1}$ Department of Agricultural and Biological Engineering, Purdue University, West Lafayette, IN 47907, USA

${ }^{2}$ Department of Agricultural and Biological Engineering, and Department of Earth and Atmospheric Sciences, Purdue University, West Lafayette, IN 47907, USA

${ }^{3}$ Department of Civil and Environmental Engineering, Colorado State University, Fort Collins, CO 80523, USA

${ }^{4}$ Agricultural and Biological Engineering, Purdue University, IN 47906, USA

Received: 29 May 2008 - Accepted: 2 June 2008 - Published: 11 July 2008

Correspondence to: I. Chaubey (ichaubey@purdue.edu)

Published by Copernicus Publications on behalf of the European Geosciences Union.

HESSD

$5,1821-1862,2008$

BMP optimization tool for pesticide control

C. Maringanti et al.

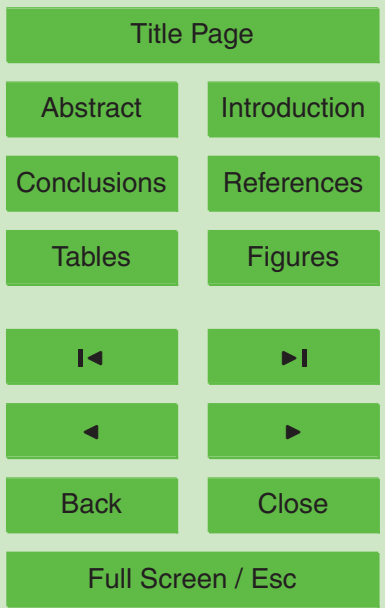

Printer-friendly Version

Interactive Discussion 


\section{Abstract}

Pesticides (particularly atrazine used in corn fields) are the foremost source of water contamination in many of the water bodies in Midwestern corn belt, exceeding the 3 ppb MCL established by the U.S. EPA for drinking water. Best management practices 5 (BMPs), such as buffer strips and land management practices, have been proven to effectively reduce the pesticide pollution loads from agricultural areas. However, selection and placement of BMPs in watersheds to achieve an ecologically effective and economically feasible solution is a daunting task. BMP placement decisions under such complex conditions require a multi-objective optimization algorithm that would search

A) satisfies the given watershed management objectives. Genetic algorithms (GA) have been the most popular optimization algorithms for the BMP selection and placement problem. Most optimization models also had a dynamic linkage with the water quality model, which increased the computation time considerably thus restricting them to apply models on field scale or relatively smaller

15 (11 or 14 digit HUC) watersheds. However, most previous works have considered the two objectives individually during the optimization process by introducing a constraint on the other objective, therefore decreasing the degree of freedom to find the solution. In this study, the optimization for atrazine reduction is performed by considering the two objectives simultaneously using a multi-objective genetic algorithm (NSGA-II). The limitation with the dynamic linkage with a distributed parameter watershed model was overcome through the utilization of a BMP tool, a database that stores the pollution reduction and cost information of different BMPs under consideration. The model was used for the selection and placement of BMPs in Wildcat Creek Watershed (located in Indiana, for atrazine reduction. The most ecologically effective solution from the model had an annual atrazine concentration reduction of $30 \%$, from the baseline with a BMP implementation cost of $\$ 18$ million. The pareto-optimal fronts generated between the two optimized objective functions can be used to achieve desired water quality goals with minimum BMP implementation cost for the watershed.

HESSD

$5,1821-1862,2008$

BMP optimization tool for pesticide control

C. Maringanti et al.

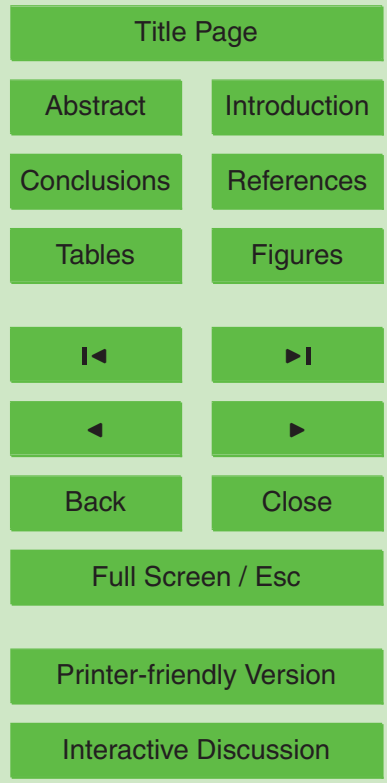




\section{Introduction}

Atrazine (6-chloro- N2-ethyl-N4-isopropyl-1,3,5-triazine-2,4-diamine) is a widely used pesticide in USA with an average annual application of 55 million pounds of active ingredient (a.i.) in USA (USDA, 2007). Atrazine is extensively used as an herbicide in 5 corn production to control broadleaf weeds. In Midwestern states, the application of atrazine in corn usually benefits in enhancing the crop yields. However, the pollution of surface and ground water bodies has exposed atrazine to humans via drinking water and the food chain. The United States Environmental Protection Agency (USEPA) has set a Maximum Contaminant Level Goal (MCLG) of 3 parts per billion ( $p p b$ or $\mu \mathrm{g} / \mathrm{L}$ ) for

atrazine in drinking water. A survey of water quality from drinking water plants indicates the presence of atrazine in $90.5 \%$ of the water samples, and $14 \%$ of the samples exceed the EPA atrazine MCL of 3 ppb (Monsanto, 2001). This problem can be expected to increase in the future with emphasis on increased corn production to meet bio-fuel (ethanol) demands. Ethanol production in the United States is predominately (>95\%) 15 grain based, primarily from corn (Schoonover and Muller, 2006). The increase in corn acreages is expected to increase the NPS pollutants (N, P, and sediment) downstream (Gulf of Mexico and Atlantic coastal waters) of the expanding production areas (Simpson et al., 2008).

Best management practices (BMPs), when implemented properly in agricultural 20 farms, are proven to be effective in controlling the movement of pesticides into the receiving water bodies (Fulton et al., 1999; Ritter and Shirmohammadi, 2001). The Farm Bill (2002) provided up to $\$ 13$ billion for conservation programs for six years aimed at protecting water quality from NPS pollutants (http://www.nrcs.usda.gov/ABOUT/ legislative/pdf/SectionbySection5-7.pdf). For example, the National Resources Con25 servation Service (NRCS) in Indiana provides millions of dollars to farmers by accommodating annual rental payment and cost share for the establishment of BMPs on eligible acreages through the Continuous Conservation Reserve Program (CCRP), Environmental Quality Incentive Program (EQIP), and Lake And River Enhancement
HESSD

$5,1821-1862,2008$

\section{BMP optimization tool for pesticide control}

C. Maringanti et al.

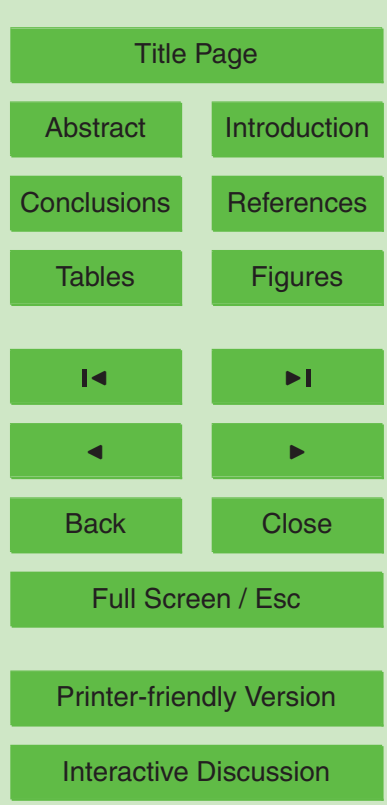


(LARE) program. Effectiveness of such programs in reducing NPS pollution is possible only through development of a watershed management tool that selects farms for the placement of BMPs in a cost effective manner.

Selection and placement of BMPs in a farm is constrained by several factors that are 5 based on ecological, economical and crop management criteria. Although, BMPs are selected for placement at the farm level, it is required that the water quality standards are achieved at the watershed scale to meet the Total Maximum Daily Load (TMDL) goals. The goal of BMP implementation plans is to achieve the maximum pollution reduction in the watershed. However, this goal is often not accomplished where, in 10 most cases, the monetary resources available for BMP implementation and maintenance, is the limiting factor. Therefore, it is desirable to select a set of BMPs, that when implemented at a farm level in the watershed would give the most reduction in pollutant load subject to minimal implementation and maintenance costs in the watershed. This requires a balance to be achieved between the ecological and economic implications of BMP implementation given cost constraints to implement BMPs in all agricultural fields within a watershed. For a given watershed with many farms and multiple BMP options in each farm, there can be many different ways of targeting BMPs and it is desirable to find solutions that give cost effective pollution reduction. Finding such solutions through on-site evaluation of different plans for targeting the BMPs in a watershed becomes highly complex as the number of farms in the watershed increase. For example, a watershed consisting of 500 farms with four possible BMPs for every farm would require $4^{500}\left(\sim 10^{300}\right)$ evaluations, which makes the targeting and evaluation method practically unfeasible. Another alternative could be random placement of BMPs in the watershed. Such a solution does not yield an optimal solution. Therefore, an efficient development of a watershed management plan requires an optimization technique for BMP selection and placement. The optimization technique searches for the best solution among the various different possibilities to achieve maximum pollutant reduction with minimum increase in cost due to the placement and maintenance of BMPs. The BMP optimization problem usually contains a large search domain for the

HESSD

$5,1821-1862,2008$

BMP optimization tool for pesticide control

C. Maringanti et al.

Title Page

Abstract

Introduction

Conclusions

Tables

References

Figures

14

$\rightarrow 1$

4

Back

Close

Full Screen / Esc

Printer-friendly Version

Interactive Discussion 
objectives and variables that needs to be solved to find an optimal solution. Heuristic search algorithms such as tabu search, simulated annealing, and genetic algorithms (GA) perform well in solving global search problems (Veith et al., 2003).

Genetic algorithm (Goldberg, 1989; Holland, 1975) is a heuristic search algorithm, 5 based on the idea of Darwin's evolutionary process. It searches the decision space based on the principles of "natural selection" and "survival of the fittest" to reach the optimal solution. GA has been used to optimize BMP selection and placement in a watershed (Arabi et al., 2006; Chatterjee, 1997; Gitau et al., 2004; Srivastava et al., 2002; Veith et al., 2003) which usually involves a large solution space to be searched 10 to find optimal solutions. However, most of the previous work has been concentrated on using a single objective function for optimization that combines BMP pollution effectiveness and net cost values for optimization (Chatterjee, 1997; Srivastava et al., 2002) or sequential optimization of BMP pollution effectiveness and cost as separate objective functions (Gitau et al., 2004; Veith et al., 2004), thus placing a constraint on one objective function during optimization of the other. The former approach does not give proper weightage to both the objective functions, and one objective function can dominate over the other, whereas, the latter approach misses some solutions by considering the two objective functions separately as both of them are dependent on each other. One exception to these approaches is a study by Bekele and Nicklow (2005) where the authors used a multi-objective optimization tool for the selection and placement of BMPs in a watershed. BMPs considered were crop management practices and did not include structural or nutrient management BMPs. Also sensitivity analysis of GA operational parameter estimation was not provided in the model.

Another limitation with most of the optimization schemes (Arabi et al., 2006; Bekele 25 and Nicklow, 2005; Srivastava et al., 2002) was the computation time. As a watershed model was dynamically linked with the optimization model, the computation time for the optimization process was typically days due to a large computation time needed to run the watershed models. The large computation cost associated with watershed model runs restricted the researchers to test their models on relatively small water-
HESSD

$5,1821-1862,2008$

BMP optimization tool for pesticide control

C. Maringanti et al.

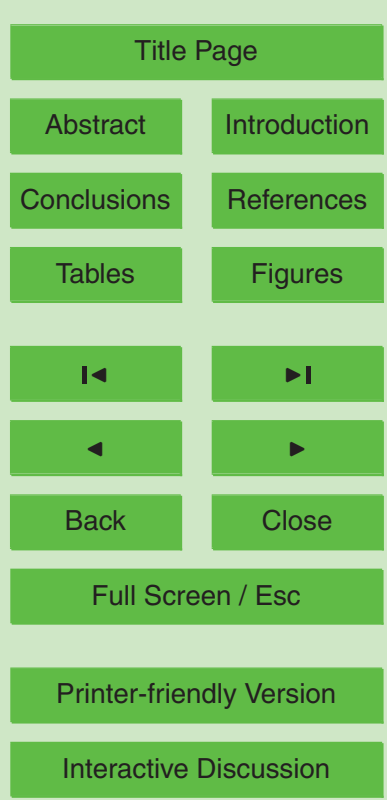


sheds ranging in size from 3 to $133 \mathrm{~km}^{2}$. These methods could not be implemented for large watersheds, e.g. 8-digit hydrologic unit code watersheds with areas typically in the range of $1400-3000 \mathrm{~km}^{2}$.

As the pesticide application and the risk of associated water pollution increases in 5 the future due to increased corn production to meet biofuel demand, it is important to develop a strategy to optimize BMP placement in a watershed to minimize this problem by providing cost effective solutions. In this paper a multi-objective optimization technique developed in a previous research (Maringanti, 2008), that incorporates a BMP tool and removes the dynamic linkage in the model architecture, is applied in Wildcat Creek Watershed located in northcentral Indiana for pesticide control.

The overall goal of this study is to apply a genetic algorithm based multi-objective optimization tool, utilizing BMP tool to efficiently optimize the selection and placement of BMPs in a watershed based on land use constraints. The two objectives that need to be optimized are minimization of the total atrazine concentration and minimization of net cost increase because of the placement of BMPs in the watershed. The multiobjective optimization tool provides a trade off (pareto-optimal front), for the near optimal solution, between the two conflicting objective functions. The pareto-optimal fronts generated using the tool aids a decision maker to choose, from a range of solutions, a solution that would meet the cost constraint to give the best possible ecologically effective solution.

\section{Theoretical background}

\subsection{Multi-objective optimization algorithm (MOOA)}

The two most popular multi-objective optimization techniques available today are Nondominated Sorted Genetic Algorithm (NSGA-II; (Deb, 1999, 2001; Deb et al., 2002) dominated sorted genetic algorithm (NSGA-II) (Deb, 1999, 2001; Deb et al., 2002) is a

HESSD

5, 1821-1862, 2008

BMP optimization tool for pesticide control

C. Maringanti et al.

Title Page

Abstract

Introduction

Conclusions

Tables

References

Figures

14

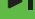

4

Back

Close

Printer-friendly Version

Interactive Discussion 
multi-objective optimization algorithm that can search a large number of variables and objective functions space to find an optimal solution. The overall computation complexity of the algorithm is $\mathrm{O}\left(\mathrm{MN}^{2}\right)$, which usually is $\mathrm{O}\left(\mathrm{MN}^{3}\right)$ for most of the evolutionary techniques (Deb et al., 2002), where O stands for "order of", M stands for the number 5 of objective functions, and $N$ stands for the population size.

Genetic algorithms (GAs) optimization procedures belong to the family of evolutionary algorithms that mimic the natural evolutionary processes to search optimal solutions for diverse, complex, and globally distributed problems. In brief, GA consists of a population of solutions that are initialized randomly and their fitness is estimated 10 by evaluating the objective functions. In the selection process, the fittest individuals are duplicated and the weak ones are discarded. The resulting population undergoes genetic modification through crossover and mutation to reach a next generation of species. This process is repeated until the near optimal solution is reached, or the specified maximum number of generations is reached.

15 The genetic algorithms have undergone many conceptual changes since they were first introduced by Holland (1975). The important development during the last decade being the extension of the single objective genetic algorithm into a multi-objective genetic algorithm that would find solutions from conflicting objective functions. Single objective genetic algorithm solves the solution space to find a single solution that is

a near optimal solution for the given objective function. However, in multi-objective optimization there is not a single optimal solution for the given problem, instead the interactions of conflicting objective functions yield a range of non-dominated solutions known as Pareto-optimal solutions (Deb, 2001).

\subsubsection{Coding}

25 Representation of variables in a problem through genetic algorithm, termed as coding, is either done through binary parameters or real valued parameters. In a binary coded $\mathrm{GA}$, the variable is decoded into a binary string (consisting of 0 and 1 ). Such a representation is beneficial when the solution space is discrete. In contrast, a real coded GA
HESSD

$5,1821-1862,2008$

BMP optimization tool for pesticide control

C. Maringanti et al.

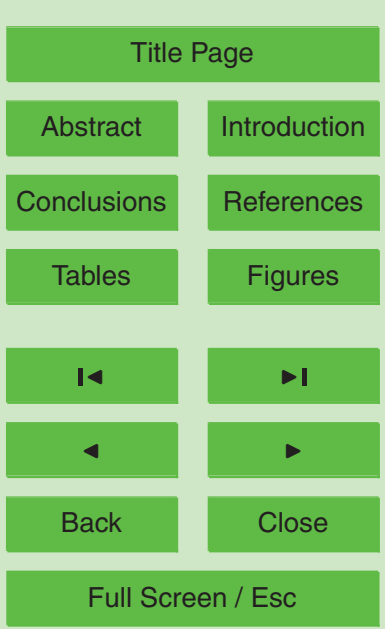

Printer-friendly Version

Interactive Discussion 
represents variables without any modification in their real valued formats. Real coded GA performs well when the solution space is continuously varying and representation through a binary string is not appropriate. A binary coded GA for optimization is utilized in this study.

\section{$5 \quad 2.1 .2$ Selection}

The goal of selection in multi-objective GA is to duplicate the good individuals (solutions) and eliminate bad individuals (solutions). For example, in a tournament selection, a common selection technique used, a tournament is conducted between two individuals picked randomly from a pool consisting of $2 \mathrm{~N}$ individuals (including $N$ repeated individuals). The tournament is won by the individual that is fittest, thus keeping the strong solutions and eliminating the weaker ones. Considering the fact that the selection operation is performed on the fitness value, any selection operator can be chosen for binary and real coded GAs. Although the selection process duplicates individuals, it cannot create new individuals (solutions). Crossover and mutation are the genetic modification processes that produce new individuals during a particular generation.

\subsubsection{Crossover}

Crossover is very important in guiding the search process towards the near optimal solutions. The crossover operation, when applied to two individuals in the mating pool of a binary coded genetic algorithm, randomly selects a portion of the chromosome string which is swapped between each other. A simple example would be a single point crossover where a single point is chosen from both the strings and all the values to the right of the point are swapped (Fig. 1). A fixed percentage of the population from the mating pool undergoes crossover. In a uniform crossover, an offspring is generated by selecting every bit with a probability "p" from either parent which then gets swapped between each other. In Fig. 2 the two strings undergo crossover with a probability of 0.5 , i.e. half the string gets exchanged at $2,3,5,7$, and 9 bits.
HESSD

$5,1821-1862,2008$

BMP optimization tool for pesticide control

C. Maringanti et al.

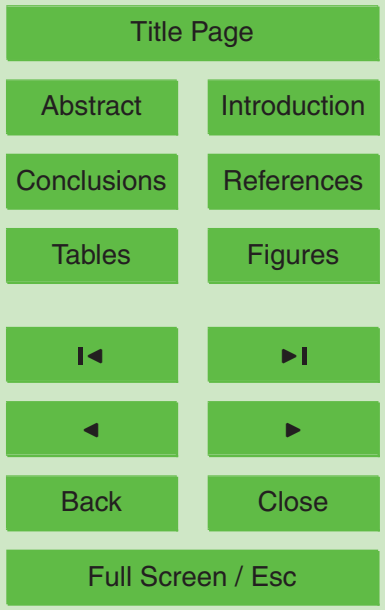

Printer-friendly Version

Interactive Discussion 
However, it is challenging to perform crossover operation in a real coded GA where a pair of real valued parameters is to be used to generate offspring. Deb and Agrawal (1995) developed simulated binary crossover (SBX) to address this problem. SBX is an analogy of single point crossover in binary coded GA, as shown in Eq. 1 5 which generates two offspring $c_{1, i}, c_{2, i}$ from two parent real valued solutions $p_{1, i}, p_{2, i}$.

$c_{1, i}=\frac{1}{2}\left[\left(1-\beta_{i}\right) p_{1, i}+\left(1+\beta_{i}\right) p_{2, i}\right]$
$c_{2, i}=\frac{1}{2}\left[\left(1+\beta_{i}\right) p_{1, i}+\left(1-\beta_{i}\right) p_{2, i}\right]$

$\beta_{i}$ is a spread factor defined as the ratio between the offspring values to that of the parents. $\beta_{i}$ can be derived from the above equation as:

$\beta_{i}=\left|\frac{c_{2, i}-c_{1, i}}{p_{2, i}-p_{1, i}}\right|$

${ }_{10} \beta_{i}$ is a sample from a random number with a density distribution (Eq. 3) where $\eta_{c}$ is the distribution index for crossover.

$p(\beta)=\frac{1}{2}\left(\eta_{c}+1\right) \beta^{\eta_{c}}$, if $0 \leq \beta \leq 1$

$p(\beta)=\frac{1}{2}\left(\eta_{c}+1\right) \frac{1}{\beta^{\eta_{c}+2}}$, if $\beta>1$

This distribution is obtained from a uniformly sampled random number $u$ between $(0,1)$ as shown in Eq. 4.

$\beta(u)=(2 u)^{\frac{1}{\eta+1}}$

$15 \quad \beta(u)=\frac{1}{(2(1-u))^{\frac{1}{\eta+1}}}$

To summarize the SBX algorithm, first choose a random number $u \in[0,1]$ to calculate $\beta_{i}$ using Eq. 4. Subsequently, $\beta_{i}$ is input into Eq. 1 to estimate the two offspring from the given two parents.
HESSD

$5,1821-1862,2008$

BMP optimization tool for pesticide control

C. Maringanti et al.

Title Page

Abstract

Introduction

Conclusions

References

Tables

Figures

14

$\rightarrow$

4

Back

Close

Full Screen / Esc

Printer-friendly Version

Interactive Discussion 
In a binary GA string of chromosome, when a bitwise mutation is performed, the value in that particular bit is changed from 0 to 1 or vice versa with a mutation probability of $p_{m}$. Goldberg (1989) introduced the "mutation clock" operator to overcome the huge 5 computational complexities of bitwise mutation. In mutation clock, the next bit to be mutated is identified for any random number $r$ (between 0 and 1) by skipping $\eta=-$ $p_{m} \ln (1-r)$ bits from the present bit, therefore, reducing the number of random numbers to be generated by $\mathrm{O}\left(1 / p_{m}\right)$.

Real code GA requires a different mutation methodology so that the real values are 10 perturbed around their current values to generate mutated children $c_{k}$ from parent $p_{k}$ (Eq. 5)

$c_{k}=p_{k}+\left(p_{k}^{u}-p_{k}^{\prime}\right) \delta_{k}$

where $p_{k}^{\prime}$ and $p_{k}^{u}$ are the upper and lower bound of the parent, and $\delta_{k}$ is small variation which is calculated from a polynomial distribution using Eq. 6.

\section{HESSD}

$5,1821-1862,2008$

\section{BMP optimization tool for pesticide control}

C. Maringanti et al.

${ }_{15} \begin{aligned} & \delta_{k}=\left(2 r_{k}\right)^{\frac{1}{\eta_{m}+1}}-1, \text { if } r_{k}<0.5 \\ & \delta_{k}=1-\left(2\left(1-r_{k}\right)\right)^{\frac{1}{\eta_{m}+1}}, \text { if } r_{k} \geq 0.5\end{aligned}$

GA operators, namely selection, crossover, and mutation are common for both single and multi-objective genetic algorithms. However, multi-objective GA requires a range of solutions from the conflicting objective functions. Non-dominance and elitism are techniques that are applied in multi-objective GA to ensure that the near optimal solution reached is as close as possible to the global optima and that the solutions are as distinct as possible.

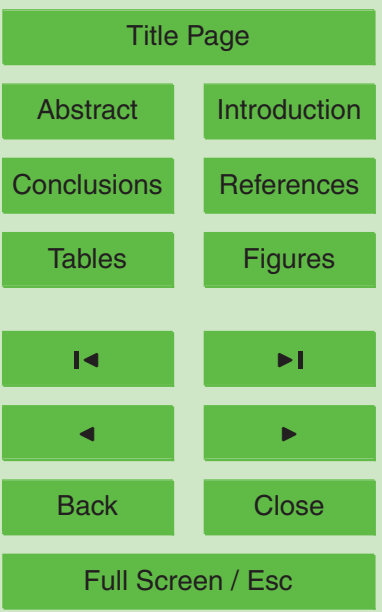

Printer-friendly Version

Interactive Discussion 
In a multi-objective optimization problem, if $g_{i},\{\mathrm{i}=1, \ldots M\}$ are the objective functions that need to be minimized, a solution $x^{(1)}$ is said to dominate $x^{(2)}$ if both of the following conditions are true (Zitzler and Thiele, 1999):

HESSD

$5,1821-1862,2008$

BMP optimization tool for pesticide control

C. Maringanti et al.

i.e. $x^{(2)}$ is dominated by $x^{(1)}$ or in other words . $x^{(1)}$ is non dominated by $x^{(2)}$.

If each individual in a population of size $N$ has solutions that are non-dominated, then the representative of the solutions in the objective space determines the pareto optimal front. The objective of multi-objective optimization is to search for solutions that 10 would help in achieving the global pareto-optimal region (i.e. optimal for all the objective functions) and to achieve solutions that are as far as possible from each other in the non-dominant front. This also helps in checking the premature convergence of the optimization process (Deb et al., 2002).

\subsubsection{Elitism and crowding distance}

15 There always exists a set of best solutions at each generation, whose size can be comparable to the population size $N$ that can go along to the next generation. Such solutions that are non-dominated among all the individual generations are called elite solutions and are stored in an external set called the elite set. After every generation a percentage of population is replaced by individuals from the elite set to ensure that the optimization algorithm reaches the global optimal solution.

Crowding distance is half the perimeter of the maximum hypercube allowed around a solution without including any solution from the same non-dominated front and is

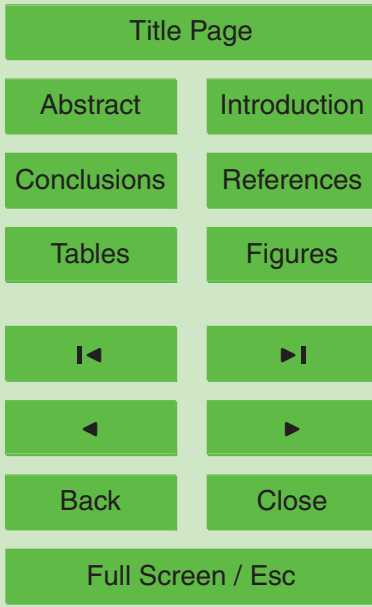

Printer-friendly Version

Interactive Discussion 
used by the NSGA-II to ensure that the solutions generated at each generation are well spread along the pareto-optimal front and are far apart in the solution space.

\subsection{Description of the watershed model}

The watershed model used in this study was Soil and Water Assessment Tool (SWAT).

5 The SWAT is a process based distributed parameter watershed scale simulation model designed for use in gauged as well as ungauged basins to simulate long term effects of various watershed management decisions on hydrology and water quality response (Arnold et al., 1998). It performs well for long-term continuous simulations at both monthly and annual scales (Borah and Bera, 2004; Gassman et al., 2007). The SWAT model divides the watershed into subwatersheds or subbasins based on the outlets selected within the watershed by the user. Subbasins are further divided into land areas, called hydrologic response units (HRUs), based on land use, management, and soil properties. The climatic input data required by SWAT are precipitation and temperature, solar radiation, relative humidity, and wind speed on a daily or subdaily basis from multiple climatic gauge locations. SWAT simulates the flow, nutrients, sediment, and chemicals at the subbasin or HRU level. Surface runoff is computed using a modification of the SCS curve number technique or Green and Ampt infiltration method.

SWAT algorithms for the processes that govern the fate and transport of pesticides, wash-off, degradation, and leaching, were adapted from GLEAMS (Leonard et al., 20 1987). Wash-off of the pesticide from the plant foliage occurs when the rainfall on a given day exceeds $2.54 \mathrm{~mm}$ (Neitsch et al., 2002) as shown in equation Eq. 8:

$$
P_{f, w s h}=f_{w s h} \times P_{f}
$$

where $P_{f, w s h}(\mathrm{~kg} / \mathrm{ha})$ is the amount of pesticide that is washed-off from the plant foliage, $f_{w s h}$ is the fraction of total pesticide that is washed off, and $P_{f}(\mathrm{~kg} / \mathrm{ha})$ is the total
HESSD

5, 1821-1862, 2008

BMP optimization tool for pesticide control

C. Maringanti et al.

Title Page

Abstract

Introduction

Conclusions

Tables

References

Figures

14

$\rightarrow$

4

Back

Close

Printer-friendly Version

Interactive Discussion ing atrazine, are organic compounds containing carbon which are degraded by micro 
organisms. The degradation typically follows first order kinetics for pesticide present in both soil and plant foliages (Eq. 9).

$P_{t}=P_{t=0} \times e^{\left|-k_{p} \times t\right|}$

where $P_{t}$ is pesticide concentration at time $t(\mathrm{~s}), P_{t=0}$ is the initial concentration of pesti5 cide $(\mathrm{mg} / \mathrm{L})$, and $k_{p}$ is the rate constant for pesticide degradation (1/s). Pesticide transport through surface runoff occurs in solution or adsorbed forms. Pesticide distribution in soil and soluble phases are represented using a linear isotherm (Vazquez-Amabile et al., 2006):

$K_{d}=\frac{C_{s}}{C_{w}}$

10 where $K_{d}$ is the partitioning coefficient $(\mathrm{mL} / \mathrm{g}), C_{s}$ is the concentration in solid phase $(\mathrm{mg} / \mathrm{kg})$, and $C_{w}$ is the concentration in the solution phase $(\mathrm{mg} / \mathrm{L})$. The SWAT model considers one pesticide at a time to incorporate routing and in-stream pesticide transformations (Neitsch et al., 2002) based on the equations proposed by Chapra (1997).

An important feature in SWAT is that it aids in modeling the various BMPs (structural 15 and management based) by changing appropriate parameters in the input files of the model. This feature was utilized in the development of a BMP tool which estimates the effectiveness of BMPs for a particular pollutant reduction.

\section{Methodology}

Figure 3 describes the flow chart for the processes that follow during the multi-objective optimization. The variables (equal to the number of HRUs) are initiated randomly for a given population size. The SWAT model output that gives the baseline atrazine loading at an HRU level in the watershed, an allele set that provides land use constraints for the placement of BMPs, and a BMP tool that provides atrazine reduction efficiency
HESSD

$5,1821-1862,2008$

BMP optimization tool for pesticide control

C. Maringanti et al.

Title Page

Abstract

Introduction

Conclusions

Tables

References

Figures

14

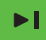

4

Back

Close

Full Screen / Esc

Printer-friendly Version

Interactive Discussion 
and corresponding costs for implementation of BMPs are required by the optimization algorithm to evaluate the objective function for the initialized population. The population then undergoes selection and genetic operations (mutation and crossover) to create population for the next generation. After every generation a check is performed to see

5 if the generation number has exceeded the fixed maximum generations. The model terminates when the maximum generation is reached, which is the stopping condition, to provide a range of optimized solutions for the two objective functions at the final generation of the optimization.

\subsection{Study watershed}

10 Wildcat Creek (WCC) watershed (Fig. 4) (USGS 8 digit Hydrologic Unit Code or HUC 05120107 ) with a drainage area of $1956 \mathrm{~km}^{2}$, located in northcentral Indiana was used for testing the optimal BMP selection and placement. The watershed is predominately agricultural with $74 \%$ row crops (36\% Soybean, $38 \%$ Corn), $21 \%$ pasture, and $3 \%$ urban area (USDA-NASS, 2001) with a mean annual precipitation of $1054 \mathrm{~mm}$. The watershed has a flat terrain and has an average slope of $1.5 \%$. The high pesticide (atrazine) level from the agricultural areas has degraded the water quality in this watershed and represents water quality problems in many agricultural watersheds in Indiana in general and Wildcat Creek Watershed in particular (Homes et al., 2001). 117 water bodies in the watershed are listed in the 303(d) list of impaired water bodies. Phosphorus concentrations in the watershed streams are considered to be highly elevated and studies have shown that most of the streams violate ammonia standards (WCW, 2003). Various NPS pollution reduction projects are being undertaken in the watershed. However, success for these projects can be increased by evaluating the efficiency of various BMP selection decisions and implementing those with the greatest economical and ecological benefits.

HESSD

5, 1821-1862, 2008

BMP optimization tool for pesticide control

C. Maringanti et al.

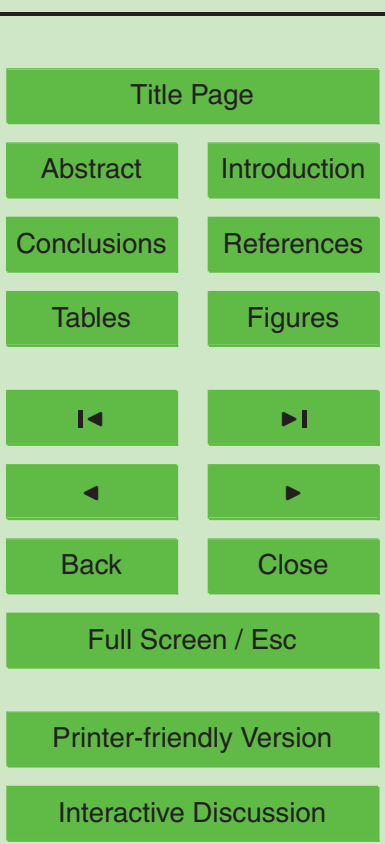


SWAT was used to delineate the watershed into 109 subbasins and the subbasins were further divided into 403 hydrological response units (HRU). An HRU is defined as a region with similar land use and soil distributions in the subbasin. For the analysis 5 each HRU was approximated to be a farm, and the BMPs were selected for placement at each of the HRUs.

The flow information for the watershed was obtained from three USGS gauging sites (Fig. 4). The SWAT model was calibrated for flow at these gauging stations using coefficient of determination $\left(R^{2}\right)$ and Nash-Sutcliffe efficiency coefficient $\left(R_{N S}^{2}\right)$ as the 10 objective functions. Calibration for pesticide was performed for one IDEM (Indiana Department of Environmental Monitoring) water quality gauging site. Pesticide measurements were available for only for a few days during a year. Therefore, pesticide calibration was performed in such a manner that the difference between the total annual average of pesticide measured and simulated was the least. The calibrated model 15 was used in further analysis to simulate pesticide in its adsorbed and dissolved forms. An average annual atrazine load from each HRU was considered in the study. The calibration details for flow and pesticide are provided in Figs. 5 and 6, respectively.

\subsection{Allele set preparation}

The BMPs are land use and land cover specific, i.e. every land use has a unique set of 20 BMPs that is feasible to be implemented in the particular region. These sets of BMPs are called allele sets and serve as an input in the optimization model by narrowing the search space for a given land use to a definite set of BMPs that can be selected.

Table 1 shows the allele set for different crops in the Wildcat Creek Watershed. For the case of atrazine reduction, the BMPs are selected for placement in corn fields only. 25 Therefore, corn fields have four alternatives for buffer strips and two alternatives for tillage. All other farms have a value of "Null", which denotes that the search process does not change the management in these farms from the baseline scenario, thus

\section{BMP optimization tool for pesticide control}

C. Maringanti et al.

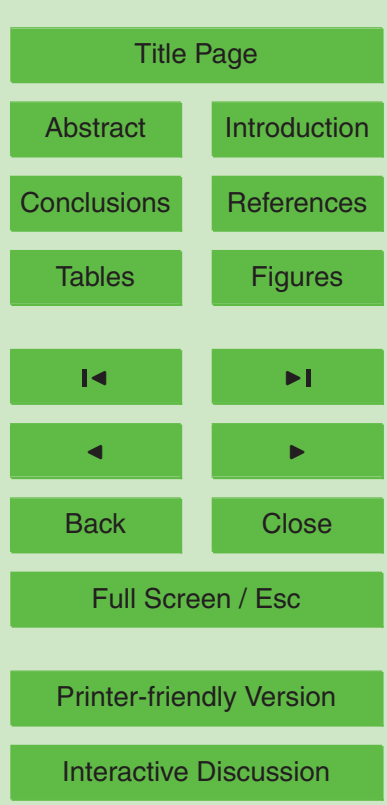


narrowing the search for finding the optimal solution.

\subsection{BMP tool}

The BMP tool provides an estimate for the costs and pollution effectiveness for each BMP that can be implemented, at a HRU scale, in the watershed. To develop the BMP tool, all the HRUs in the watershed that have a common land use are selected. The allele set is used to choose BMPs to be placed in the selected HRUs. One BMP at a time is allotted from the allele set corresponding to the chosen land use and placed in all the selected HRUs. The pollutant load in the watershed is estimated by evaluating the SWAT model, for the given BMP scenario. BMP pollution efficiency is estimated by calculating the percentage reduction in the pollution load for the BMP scenario when compared to the baseline pollutant load. The cost information is used to estimate the total costs for the placement of BMPs. This process is repeated for all possible BMPs in the allele set to develop the database that constitutes the BMP pollution reduction and corresponding BMP implementation costs. This database, called BMP tool, is used to estimate the BMP pollution reductions, thus removing the need of a dynamic linkage with the SWAT model during the optimization process.

The following assumptions were made for the development of the BMP tool:

1. The pollution reductions established by evaluating the SWAT model after each BMP placement at a watershed scale approximates the BMP pollution reduction when placed at an HRU level in the watershed.

2. The BMP reductions obtained are assumed to not vary temporally, i.e. the BMP performance remains the same throughout the time period under consideration.

3. Only one pesticide at a time can be considered in SWAT, which is a limitation with the SWAT model itself and not intrinsic to the BMP tool.

4. Routing and in stream processes are not considered when the tool is applied at an HRU level. However, in a watershed where in stream processes are highly

HESSD

$5,1821-1862,2008$

BMP optimization tool for pesticide control

C. Maringanti et al.

Title Page

Abstract Introduction

Conclusions References

Tables Figures

14

4

Back

Full Screen / Esc

Printer-friendly Version

Interactive Discussion
I

Close 
critical, the full dynamically linked optimization model needs to be used.

5. The pollution reductions established for various BMPs are specific for the watershed under consideration.

For each HRU having corn as a land use, 8 BMPs were possible considering all pos5 multiple BMPs in a single HRU. The different BMPs that are considered for placement were buffer strips of varying width $(20 \mathrm{~m}, 27 \mathrm{~m}$, and $30 \mathrm{~m}$ ), and tillage practices (no-till, and conventional tillage). Each of the possible scenarios is modeled in SWAT to simulate the pesticide output at an HRU level. Table 2 details the list of parameters and their baseline model is considered to have no buffer strip placed at any field and practicing conventional tillage in the watershed. BMP effectiveness for atrazine is computed by calculating the percentage reduction caused due to the placement of the BMP when compared to the baseline atrazine losses.

\subsubsection{Cost estimation}

The BMP costs that were used in the model were annual net costs per unit area of the watershed which included the establishment and maintenance costs. The costs for the tillage management practice in corn were obtained from the University of Illinois Extension Service publication (FEFO, 2006). The other cost information for the various BMPs for year 2007, as shown in Table 3, were obtained from Indiana Environmental Quality Incentives Program (EQIP) funded by United States Department of Agriculture - Natural Resources Conservation Service (USDA-NRCS). All the cost estimates were estimated per unit area $(\$ / \mathrm{ha})$. For each of the BMPs, the total cost was estimated by incorporating maintenance, interest rate, and design life (td) information evaluated by
HESSD

$5,1821-1862,2008$

BMP optimization tool for pesticide control

C. Maringanti et al.

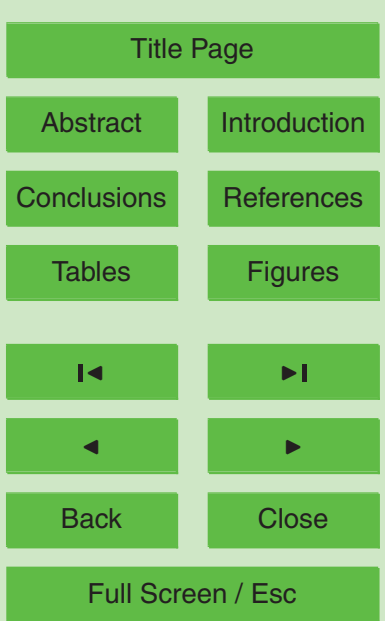

Printer-friendly Version

Interactive Discussion 


$$
\begin{aligned}
& c_{t d}(\$ / \mathrm{ha} / \mathrm{yr})=c_{0}\left((1+s)^{t d}+r m\left[\sum_{\tau=1}^{t d}(1+s)^{\tau-1}\right]\right) / t d \\
& \Rightarrow c_{t d}(\$ / \mathrm{ha} / \mathrm{yr})=c_{0}\left((1+s)^{t d}+r m\left(\frac{(1+s)^{t d}-1}{s}\right)\right) / t d
\end{aligned}
$$

Where $c_{0}$ represents the current BMP establishment costs $(\$ / \mathrm{ha}), \mathrm{rm}$ is the ratio of maintenance to establishment cost (1\% for buffer strip), $s$ is the fixed interest rate $(6 \%)$. A design life $(t d)$ of 10 years was considered for buffer strips. For tillage BMPs 5 a design life of 1 year was considered.

\subsection{Multi-objective Genetic Algorithm model development}

The 403 HRUs, delineated by SWAT, are the variables for which the BMPs are to be searched to meet the two objective functions of a) minimization of pollutant loading and b) minimization of the net cost increase at the watershed because of the placement of

BMPs at the farm (HRU) level. The chromosome string corresponding to the optimization problem consists of 403 genes (Fig. 7). The two objective functions that need to be optimized are mathematically expressed as:

$\min \left[\left(f_{i}(X)\right) \wedge\left(g_{i}(X)\right)\right] \forall i \in[$ Pesticide $]$

Total reduction in the pollution load is expressed as weighted average of the HRUs in

the watershed $f(x)$

$f_{i}(X)=\frac{\sum_{x \in X}\left(P_{i}(x) \times A(x)\right)\left(1-R_{i}(x)\right)}{\sum_{x \in X} A(x)}$
HESSD

5, 1821-1862, 2008

BMP optimization tool for pesticide control

C. Maringanti et al.

Title Page

Abstract

Introduction

Conclusions

References

Tables

Figures

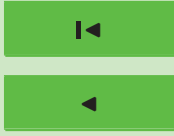

$\rightarrow$

Back

Close

Full Screen / Esc

Printer-friendly Version

Interactive Discussion 
$g_{i}(X)=\frac{\sum_{x \in X} C_{i}(x) A(x)}{\sum_{x \in X} A(x)}$

HESSD

$5,1821-1862,2008$

\section{BMP optimization tool for pesticide control} $\mathrm{HRU}, R_{i}$ is the Pollutant reduction efficiency of BMP, $A$ is the Area of $\mathrm{HRU}$; and $C_{i}$ is 5 the unit cost of the BMP.

The SWAT output (baseline scenario) for the pollutant loading at HRU level, BMP effectiveness estimated from various SWAT runs, economic data, and allele sets form the inputs for the optimization model. During the optimization process, the algorithm searches first for a particular management practice from the given allele set for a par10 ticular land use. The subsequent estimation of the pollution loading and cost estimates for the placement of this particular BMP in the selected HRU is obtained from the BMP tool. A weighted average of the pollutant loading and the net costs at HRU level is calculated to get an estimate at the watershed level (Eqs. 13 and 14).

The Pareto-optimal front (tradeoff) plot of these objective functions gives a range of 15 near optimal solutions that can be used to select the best possible pollution reduction model and the corresponding minimal net cost due to the placement of BMPs.

The various parameters of a GA are population size, number of generations, crossover rate, and mutation probability. Population size determines the number of individuals considered for the evolutionary process. The members of this population undergo genetic modifications through the process of mutation and crossover to obtain a new set of individuals that are stronger than the parent. The weaker individuals from the pool are eliminated during this process so that the number of individuals in the population remains the same but the population is more fit than before. This process is continued for a given number of iterations known as generations. Usually the performance of GA is improved by increasing the population size and number of generations, but that also increases the computation time to reach a near optimal solution.

\section{Maringanti et al.}

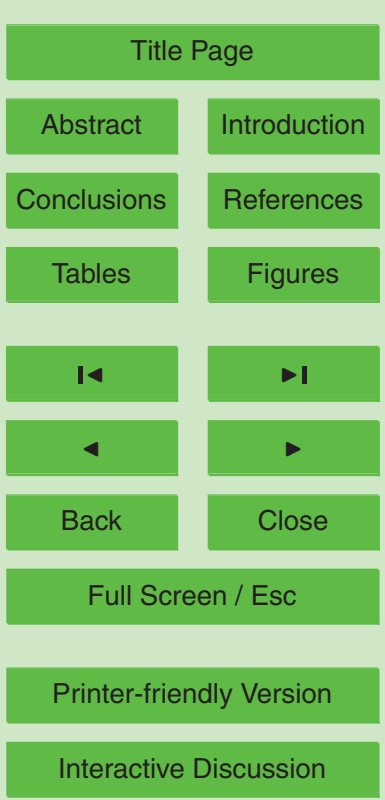

Interactive Discussion 
Crossover and mutation probability are the parameters that create the offspring, and hence are critical in driving the algorithm towards an optimal solution.

HESSD

\subsection{Sensitivity analysis and estimation of GA parameters}

A sensitivity analysis was performed on GA parameters to determine the influence of 5 these parameters on the pareto-optimal front. The various GA parameters (population size, generations, mutation, and crossover probability) were changed, one at a time, to evaluate the effects of each parameter on the Pareto front. Estimating the goodness of the pareto-optimal front is subjective. The closer the front gets to the origin; the better the solution is to minimize the two objective functions. The parameter value for which the pareto-front was closest to the origin in sensitivity analysis was taken as the parameter estimate for the optimization process.

Default genetic algorithm operational parameters were considered as shown in Table 4 . Sensitivity analysis was performed by changing a particular operational parameter while keeping the other three parameters fixed. Bounded parameters such as crossover $(0$ to 1$)$ and mutation probability were varied such that a range of values between the bounds were covered. Pareto optimal fronts were plotted after every run and the progress in the front was observed.

The total pollutant load and net cost for the placement of BMPs in the watershed was estimated from Eqs. 13 and 14. All the estimates were based on an annual average 20 per unit area in the watershed. These two objective functions are plotted against each other during every stage of the sensitivity analysis.

\section{Results and discussion}

4.1 Sensitivity and estimation of GA operational parameters

The results obtained from the optimization algorithm considering binary coding of vari- ables indicate that increasing the population size from 10 to 100 improved the perfor-
$5,1821-1862,2008$

BMP optimization tool for pesticide control

C. Maringanti et al.

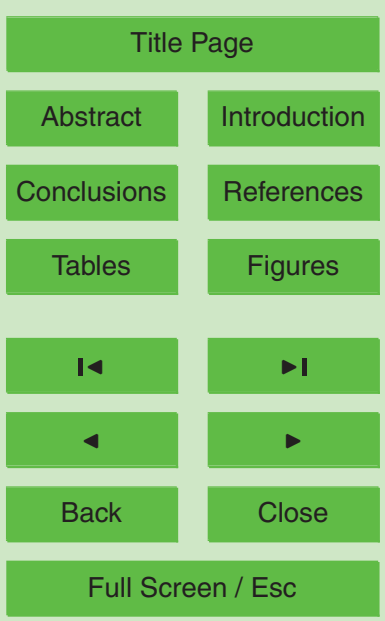

Printer-friendly Version

Interactive Discussion 
mance of the model (pareto-optimal front). However, no further improvement in the pareto-front was noticed when the population was further increased. A population size of 800 was observed to give the better spread when compared to the other sizes that were considered (Fig. 8a). As the number of generations was increased from 100 to 5 5000, an improvement in the pareto-optimal front was observed in finding better solutions and also better spread for the solutions. Further increase in the number of generations to 10000 did not display any improvement in the results compared to the results obtained at 5000 generations (Fig. 8b).

The uniform crossover operation was not as sensitive in perturbing the objective 10 space when compared to other GA parameters. As the crossover increased from 0.1 to 0.5 , the Pareto-front got closer to the origin. However, when the crossover rate was further increased to 0.9 , the Pareto-front moved away from the origin. Overall the change in the Pareto-optimal front was not very significant for different crossover fractions (Fig. 8c). Therefore, the closest front, corresponding to a crossover value of 0.5 , was chosen for the optimization process. Mutation probability operator was observed to be a very sensitive parameter (Fig. 8d). There was no particular pattern observed when the mutation operator was increased from 0.001 to 0.05 . However, a value of 0.005 provided a better solution when compared to the others. Further increasing the mutation probability (to 0.01 and 0.05 ) shifted the Pareto-optimal front further away from the origin, thus deteriorating the solution.

\subsection{Multi-objective optimization model}

Table 4 summarizes values for the genetic algorithm parameters that were used for optimization. The optimization model run with a population of 800 and 5000 generations took 2 hours to complete on a CentrinoDuo@2.16 GHz computer. If a dynamic linkage

with a hydrologic model was used during the optimization, it would have taken 45 years to complete the required model runs.

During the first generation of the genetic algorithm, the variables of the population were initiated randomly. However, for the further generations the variables were modi-

HESSD

$5,1821-1862,2008$

BMP optimization tool for pesticide control

C. Maringanti et al.

Title Page

Abstract

Introduction

Conclusions

Tables

References

Figures

14

$\rightarrow 1$

4

Back

Close

Printer-friendly Version

Interactive Discussion 
fied using the genetic operators: crossover and mutation. Figure 9 shows the progress of the Pareto-optimal front during the optimization process. Pareto optimal front for the minimization of the two objective functions tends to move towards the origin and solutions are spread to give a better choice for the solutions to be chosen. Solutions during 5 the first few generations are highly scattered and non-dominance is not exhibited by the solutions. However, as the optimization progresses the scattering of solutions is minimized, i.e. solutions are non-dominated and the pareto-front moves towards the origin. It was observed that during the optimization process, the spread of the solution was improved, thus providing a wider choice for the selection of optimized set of BMPs 10 to be placed in the watershed.

Figure 10 focuses on the solutions obtained from the final generation. A range of solutions that cost $0-075 \$ /$ ha provide reduction of $0-018.5 \%$ in atrazine concentration. The solutions from the multi-objective optimization model unlike the single solution obtained from single objective optimization models provide the decision maker choices to optimize the funds available, which is a constraint in most cases. In other cases where the goal is to obtain a solution to meet the specified TMDL goals in a watershed, the solutions should at least produce the specified reduction; therefore the optimized solution that costs the least for achieving the particular water quality goals is selected. However, if equal weight is to be given to the two objectives of pollution reduction and net cost increase, the solution that is closest to the origin is selected, i.e. a solution for which Eq. 15 is the least.

$$
\sqrt{(f(x))^{2}+(g(x))^{2}}
$$

Figure 11 demonstrates the spatial placement of BMPs in the watershed, at the HRU level. Figure 11a shows the placement of BMPs that achieve the best pollution reduction for a net cost increase of $\$ 97 /$ ha in the watershed. The BMP placement corresponding to an intermediate solution is given in Fig. 11b, where the BMP implementation has a net cost increase of $\$ 35 / \mathrm{ha}$. Figure $11 \mathrm{c}$ represents the base scenario with no increase in cost and no atrazine reduction in the watershed.

\section{HESSD}

5, 1821-1862, 2008

BMP optimization tool for pesticide control

C. Maringanti et al.

Title Page

Abstract

Introduction

Conclusions

Tables

References

Figures

14

$\rightarrow$

4

Back

Close

Full Screen / Esc

Printer-friendly Version

Interactive Discussion 


\section{Summary and conclusions}

Watershed level placement of BMPs to achieve maximum NPS pollutant reduction with minimal increase in BMP implementation costs is an active area of research. This requires finding an optimal solution from many millions of feasible alternatives for the 5 selection and placement of BMPs. The BMP optimization problem requires searching a large variable space to get an optimal solution. Genetic algorithms (GA) are search techniques which search the solution space globally and hence perform better than the local search techniques (for example back propagation, SIMPLEX (Nelder and Mead, 1965) to solve problems with large variable space. Most previous works in developing models for this problem have used GA for optimization by considering the two objectives of cost increase and pollution reduction individually by placing a constraint on one objective while optimizing the other. The drawback with this approach is that some solutions might be lost because the two objectives are considered separately. This problem is addressed through a development of a multi-objective optimization algo15 rithm framework that considers both of these objectives simultaneously in our earlier research (Maringanti, 2008). Also the other previous models developed were confined to either field scale or small watersheds $\left(\right.$ area $<13 \mathrm{~km}^{2}$ ) as most of these models used a dynamic linkage between the optimization model and the watershed simulation model, which increased the computation time considerably. In this study we have developed a BMP tool that replaces the dynamic linkage in the model architecture. The BMP tool required running the watershed simulation model for all 8 combinations of BMPs possible in the watershed. BMP pollution efficiency was computed for each combination of BMPs by comparing the pollutant load for the particular BMP placement.

The multi-objective optimization of the two objective functions was performed using 25 the genetic algorithm NSGA-II. The inputs for the optimization algorithm included initial pollutant yield from a calibrated SWAT model, allele set with various options for BMP selection in a particular land use, pollution reduction efficiencies, and cost estimates for each BMP. The SWAT model was used to simulate various BMP scenarios for the
HESSD

$5,1821-1862,2008$

BMP optimization tool for pesticide control

C. Maringanti et al.

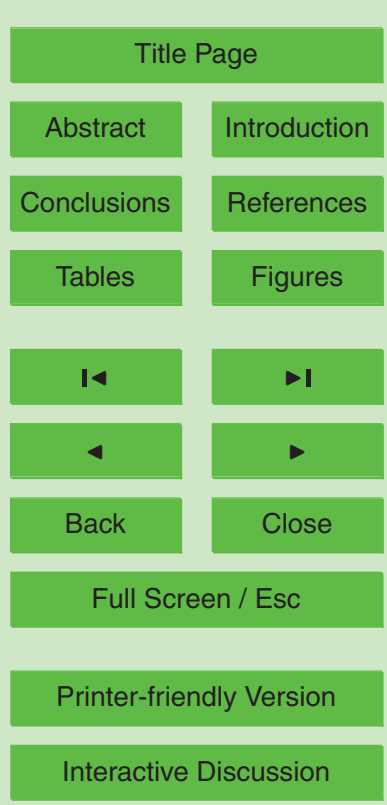


watershed; these scenarios were then used in the development of BMP tool. A sensitivity analysis of the parameters of NSGA-II was performed to find the parameters that had significant influence on the solution. This process also estimated the parameters for NSGA-II during the process. The final optimized result gave a tradeoff between 5 the two objective functions. Overall, the pesticide optimization model performed well in reducing the pollutant load from the watershed. This trade off can be used in the development of TMDLs in the watershed to meet the water quality goals by giving a cost effective solution.

The optimization model developed is a general model and is easy to extend to any 10 calibrated and BMP to be placed are chosen for different land uses. The model gives a range of options available for pollution reduction and their corresponding costs for the implementation of BMPs. This tradeoff can aid watershed modelers in TMDL development and estimate the corresponding cost for the placement of BMPs to achieve TMDL 15 goals for atrazine.

Acknowledgements. The author would like to thank the USDA-CSREES (Grant \# 07-5113003876) and Purdue University for providing funding for this study and Govindaraju S. Rao for providing helpful inputs during the progress of the research.

\section{References}

Arabi, M., Govindaraju, R. S., and Hantush, M. M.: Cost-effective allocation of watershed management practices using a genetic algorithm, Water Resources Research, 42, W10429W10429, 2006.

Arnold, J. G., Srinivasan, R., Muttiah, R. S., and Williams, J. R.: Large area hydrologic modeling and assessment - Part 1: Model development, Journal of the American Water Resources Association, 34, 73-89, 1998.

Bekele, E. G. and Nicklow, J. W.: Multiobjective management of ecosystem services by integrative watershed modeling and evolutionary algorithms, Water Resources Research, 41, W10406-10401-10410, 2005.
HESSD

5, 1821-1862, 2008

BMP optimization tool for pesticide control

C. Maringanti et al.

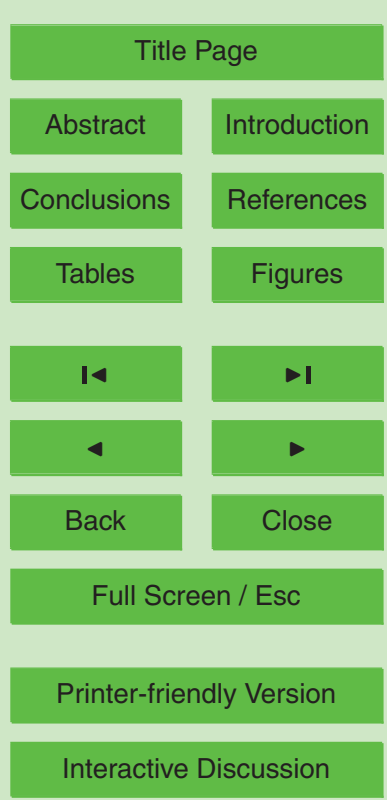


Borah, D. K. and Bera, M.: Watershed-scale hydrologic and nonpoint-source pollution models: Review of applications, Transactions of the ASAE, 47, 789-803, 2004.

Chapra, S. C.: Surface water-quality modeling, McGraw-Hill New York, 1997.

Chatterjee, A.: Watershed optimization of BMP implementation schemes using genetic algorithms, MS thesis, The Pennsylvania State University, University Park, PA., 1997.

Deb, K. and Agrawal, R. B.: Simulated binary crossover for continuous search space, Complex Systems, 9, 115-148, 1995.

Deb, K.: Multi-objective Genetic Algorithms: Problem Difficulties and Construction of Test Problems, Evolutionary computation, 7, 205-230, 1999.

10 Deb, K.: Multi-Objective Optimization Using Evolutionary Algorithms, edited by: Anonymous, John Wiley \& Sons Inc, New York, NY, 2001.

Deb, K., Pratap, A., Agarwal, S., and Meyarivan, T.: A fast and elitist multiobjective genetic algorithm: NSGA-II, IEEE Transactions on Evolutionary Computation, 6, 182-197, 2002.

FEFO: Farm Business Management. Department of Agricultural and Consumer Economics.

15 University of Illinois at Urbana-Champaign. Available at: http://www.farmdoc.uiuc.edu/ manage/newsletters/fefo06_07/fefo06_07.pdf, 2006.

Fulton, M. H., Moore, D. W., Wirth, E. F., Chandler, G. T., Key, P. B., Daugomah, J. W., Strozier, E. D., Devane, J., Clark, J. R., and Lewis, M. A.: Assessment of risk reduction strategies for the management of agricultural nonpoint source pesticide runoff in estuarine ecosystems,

20 Toxicology and Industrial Health, 15, 201, 1999.

Gassman, P. W., Reyes, M. R., Green, C. H., and Arnold, J. G.: The soil and water assessment tool: Historical development, applications, and future research directions, Transactions of the ASABE, 50, 1211-1250, 2007.

Gitau, M. W., Veith, T. L., and Gburek, W. J.: Farm-level optimization of BMP placement for cost-effective pollution reduction, Transactions of the ASAE, 47, 1923-1931, 2004.

Goldberg, D. E.: Genetic Algorithms in Search, Optimization and Machine Learning, edited by: Anonymous, Addison-Wesley Longman Publishing Co., Inc. Boston, MA, USA, 1989.

Holland, J. H.: Adaption in Natural and Artificial Systems, edited by: Anonymous, The University of Michigan Press, Ann Arbor, MI, 1975.

30 Homes, M. J., Frankenberger, J. R., and Engel, B. A.: Susceptibility of Indiana watersheds to herbicide contamination, Journal of the American Water Resources Association, 37, 9871000, 2001.

Leonard, R. A., Knisel, W. G., and Still, D. A.: GLEAMS: Groundwater Loading Effects of

HESSD

$5,1821-1862,2008$

BMP optimization tool for pesticide control

C. Maringanti et al.

Title Page

Abstract

Introduction

Conclusions

References

Tables

Figures

14

$\rightarrow$

4

Back

Close

Full Screen / Esc

Printer-friendly Version

Interactive Discussion 
Agricultural Management Systems, American Society of Agricultural Engineers, Transactions TAAEAJ, 30, 1987.

Maringanti, C.: Development of a Multi-Objective Optimization Tool for Selection and Placement of BMPs for Nonpoint Source Pollution Control, M.S., Purdue University, West Lafayette, 156 5 pp., 2008.

Monsanto: Acetochlor Reregistration Partnership Annual Report, Monsanto: St. Louis, MO, 2001.

Neitsch, S. L., Arnold, J. G., Kiniry, J. R., Williams, J. R., and King, K. W.: Soil and Water Assessment Tool Theoretical Documentation Version 2000, GSWRL Report, 02-01, 2002.

10 Nelder, J. A. and Mead, R.: A simplex method for function minimization, Computer journal, 7, 308-313, 1965.

Ritter, W. F. and Shirmohammadi, A.: Agricultural Nonpoint Source Pollution: Watershed Management and Hydrology, CRC Press, 2001.

Schoonover, H. and Muller, M.: Staying Home, How Ethanol will Change US Corn Exports, 15 Institute for Agriculture and Trade Policy, 2006.

Simpson, T. W., Sharpley, A. N., Howarth, R. W., Paerl, H. W., and Mankin, K. R.: The New Gold Rush: Fueling Ethanol Production while Protecting Water Quality, Journal of Environmental Quality, 37(2), 318, 2008.

Srivastava, P., Hamlett, J. M., Robillard, P. D., and Day, R. L.: Watershed optimization of best management practices using AnnAGNPS and a genetic algorithm, Water Resources Research, 38, 1-14, 2002.

USDA-NASS: A Crop-Specific Digital Data Layer for Indiana, 2002 March. Available at http: //www.nass.usda.gov/research/Cropland/metadata/metadata_in01.htm., 2001.

USDA: Agricultural Chemical Usage: Field Crops summary from 1992-2007. http://usda. mannlib.cornell.edu/MannUsda/viewDocumentInfo.do?documentID=1560, Accessed October 2007., 2007.

Vazquez-Amabile, G., Engel, B. A., and Flanagan, D. C.: Modeling and risk analysis of nonpoint-source pollution caused by atrazine using SWAT, Transactions of the Asabe, 49, 667-678, 2006.

30 Veith, T. L., Wolfe, M. L., and Heatwole, C. D.: Optimization procedure for cost effective BMP placement at a watershed scale, Journal of the American Water Resources Association, 39, 1331-1343, 2003.

Veith, T. L., Wolfe, M. L., and Heatwole, C. D.: COST-EFFECTIVE BMP PLACEMENT: OPTI1846
HESSD

$5,1821-1862,2008$

\section{BMP optimization tool for pesticide control}

C. Maringanti et al.

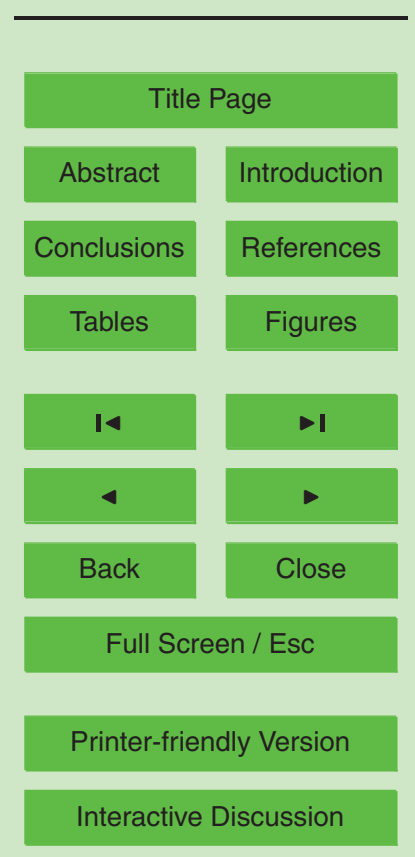

Interactive Discussion 
MIZATION VERSUS TARGETING, Transactions of the ASAE, 47, 1585-1594, 2004.

WCW: Little Wildcat Creek Watershed Management Plan, IDEM Project report, ARN \# 00-199, 2003.

Zitzler, E. and Thiele, L.: Multiobjective evolutionary algorithms: A comparative case study and 5 the Strength Pareto approach, IEEE Transactions on Evolutionary Computation, 3, 257-271, 1999.

\section{HESSD}

$5,1821-1862,2008$

\section{BMP optimization tool for pesticide control}

C. Maringanti et al.

\section{Title Page}

Abstract Introduction

Conclusions References

Tables Figures

14

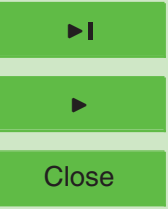

Back

\section{Full Screen / Esc}

Printer-friendly Version

Interactive Discussion 


\section{HESSD}

5, 1821-1862, 2008

\section{BMP optimization tool for pesticide control \\ C. Maringanti et al.}

Table 1. Allele set of BMPs in Wildcat Creek Watershed.

\begin{tabular}{ll}
\hline Crop & Allele set \\
\hline Corn & Buffer $20 \mathrm{~m}, 27 \mathrm{~m}$, and $30 \mathrm{~m}$ Conventional till, and No-Till \\
Soybean & "Nulll" \\
Pasture & "Null" \\
Forest & "Nulll" \\
\hline
\end{tabular}

Title Page

Abstract Introduction

Conclusions

References

Tables

Figures

I

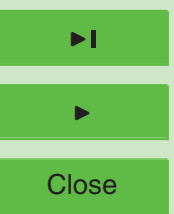

Back

Full Screen / Esc

Printer-friendly Version

Interactive Discussion 


\section{HESSD}

$5,1821-1862,2008$

\section{BMP optimization tool for pesticide control}

Table 2. Representation of best management practices in SWAT*.

C. Maringanti et al.

\begin{tabular}{llll}
\hline \multicolumn{3}{c}{ SWAT representation } \\
\hline Best Management Practice & Parameter to be changed & Parameter value & Input file \\
Buffer strips & FILTERW & width $(0,20,27$, or $30 \mathrm{~m})$ &. $\mathrm{mgt}$ \\
Tillage & Till ID & 2 (Conventional) &. $\mathrm{mgt}$ \\
& & 4 (No-Till) &. $\mathrm{mgt}$ \\
& CN2 & CN2-2 & .hru \\
\hline
\end{tabular}

* Source: Arabi et al. (2007)

Title Page

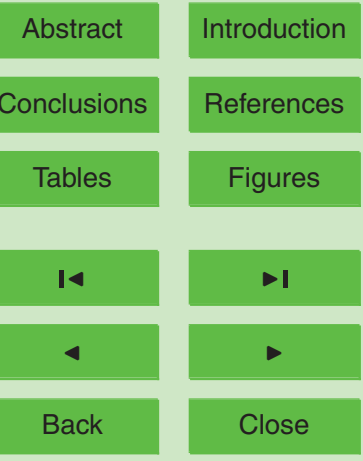

Full Screen / Esc

Printer-friendly Version

Interactive Discussion 


\section{HESSD}

$5,1821-1862,2008$

Table 3. Pollution effectiveness and cost information of best management practices used in the BMP tool.

\begin{tabular}{lllll}
\hline \multicolumn{2}{c}{ Best management practice } & Pesticide $^{\mathrm{a}}$ yield & Pesticide reduction & Net cost $^{\mathrm{a}, \mathrm{c}}$ increase \\
\hline Buffer $^{\mathrm{b}}$ width & Tillage $^{\mathrm{b}}$ practice & $\mathrm{ppb}$ & $\%$ & $\$ / \mathrm{ha}$ \\
$0 \mathrm{~m}$ & Conventional $_{0 \mathrm{~m}}$ & 0.71 & - & - \\
$20 \mathrm{~m}$ & No-Till & 0.66 & $7.1 \%$ & -3 \\
$20 \mathrm{~m}$ & Conventional & 0.42 & $41.9 \%$ & 245 \\
$27 \mathrm{~m}$ & No-Till & 0.42 & $41.4 \%$ & 242 \\
$27 \mathrm{~m}$ & Conventional & 0.39 & $45.7 \%$ & 327 \\
$30 \mathrm{~m}$ & No-Till & 0.40 & $44.4 \%$ & 324 \\
$30 \mathrm{~m}$ & Conventional & 0.38 & $46.9 \%$ & 409 \\
\hline
\end{tabular}

\section{BMP optimization tool for pesticide control}

C. Maringanti et al.

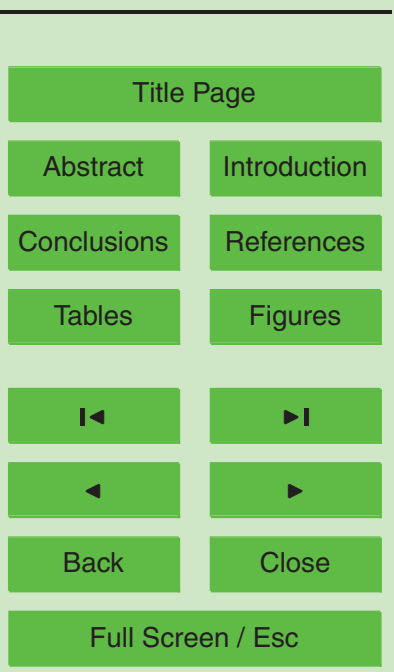

Printer-friendly Version

a Pesticide yield and costs are quoted per annum.

${ }^{\mathrm{b}}$ Conventional till with no buffer strip considered baseline.

${ }^{c}$ Costs include the interest $(=6.5 \%)$ and maintenance rates $(=1 \%$ for buffer strips). Source: Arabi et al., (2006).

Costs for no-till and conventional till obtained from the University of Illinois extension service publication.

Accesible at: http://www.farmdoc.uiuc.edu/manage/newsletters/fefo06_07/fefo06_07.pdf 


\section{HESSD}

$5,1821-1862,2008$

\section{BMP optimization tool for pesticide control}

C. Maringanti et al.

Table 4. Default and optimal parameters chosen for GA from sensitivity analysis.

\begin{tabular}{lll}
\hline Parameter & Default & Optimal \\
\hline Population & 400 & 800 \\
No. of generations & 500 & 5000 \\
Crossover probability & 0.7 & 0.5 \\
Mutation probability & 0.001 & 0.001 \\
\hline
\end{tabular}

Title Page

Abstract

Introduction

Conclusions

References

Tables

Figures

14

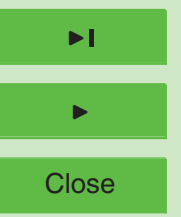

Back

Close

Full Screen / Esc

Printer-friendly Version

Interactive Discussion 


\section{HESSD}

$5,1821-1862,2008$

\section{BMP optimization tool for pesticide control}

C. Maringanti et al.

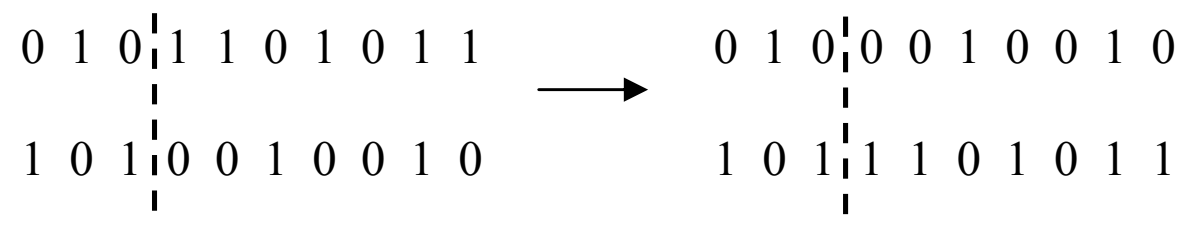

Title Page

Abstract

Introduction

Conclusions

References

Tables

Figures

Fig. 1. Single point crossover of two chromosome strings.

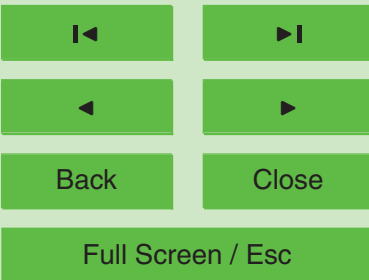

Printer-friendly Version

Interactive Discussion 


\section{HESSD}

$5,1821-1862,2008$

\section{BMP optimization tool for pesticide control}

C. Maringanti et al.

$$
\begin{aligned}
& \begin{array}{lllllllllll}
0 & 1 & 0 & 1 & 1 & 0 & 1 & 0 & 1 & 1
\end{array} \longrightarrow \begin{array}{llllllllll}
0 & 0 & 1 & 1 & 0 & 0 & 0 & 0 & 1 & 1
\end{array} \\
& \begin{array}{llllllllllllllllllll}
1 & 0 & 1 & 0 & 0 & 1 & 0 & 0 & 1 & 0 & 1 & 1 & 0 & 0 & 1 & 1 & 1 & 0 & 1 & 0
\end{array}
\end{aligned}
$$

Title Page

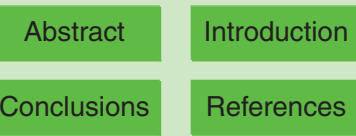

Tables

Figures

Fig. 2. Uniform crossover of two chromosome strings.

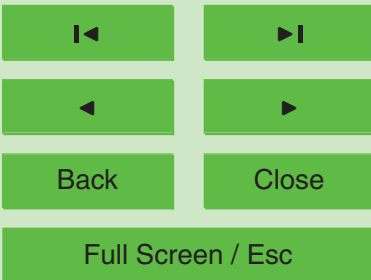

Printer-friendly Version

Interactive Discussion 


\section{HESSD}

5, 1821-1862, 2008

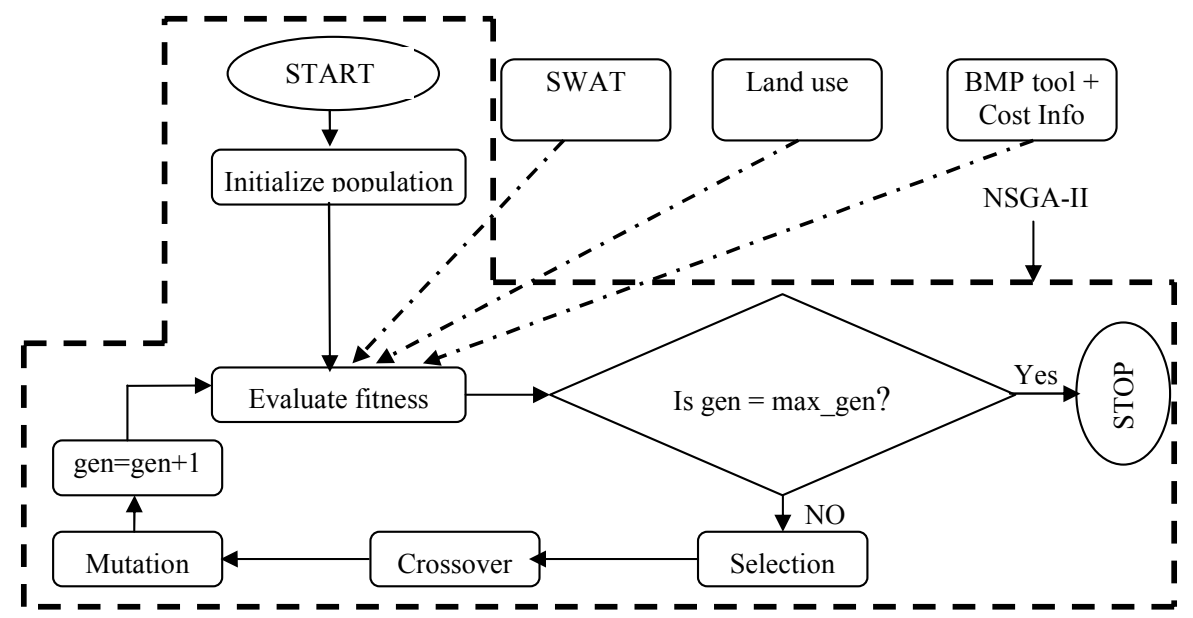

BMP optimization tool for pesticide control

C. Maringanti et al.

Title Page

Abstract

Introduction

Conclusions

References

Tables

Figures

14

$>$ I

4

Back

Close

\section{Full Screen / Esc}

Printer-friendly Version

Interactive Discussion 


\section{HESSD}

5, 1821-1862, 2008

BMP optimization tool for pesticide control

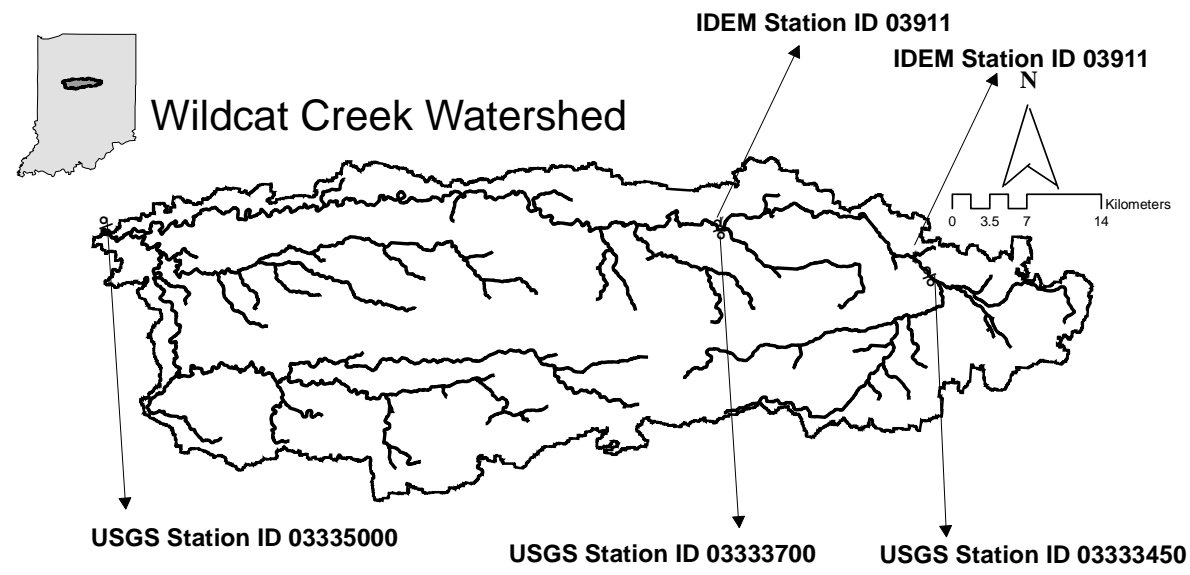

C. Maringanti et al.

Title Page

Abstract

Introduction

Conclusions

References

Tables

Figures

14

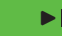

4

Back

Close

Full Screen / Esc

Printer-friendly Version

Interactive Discussion 

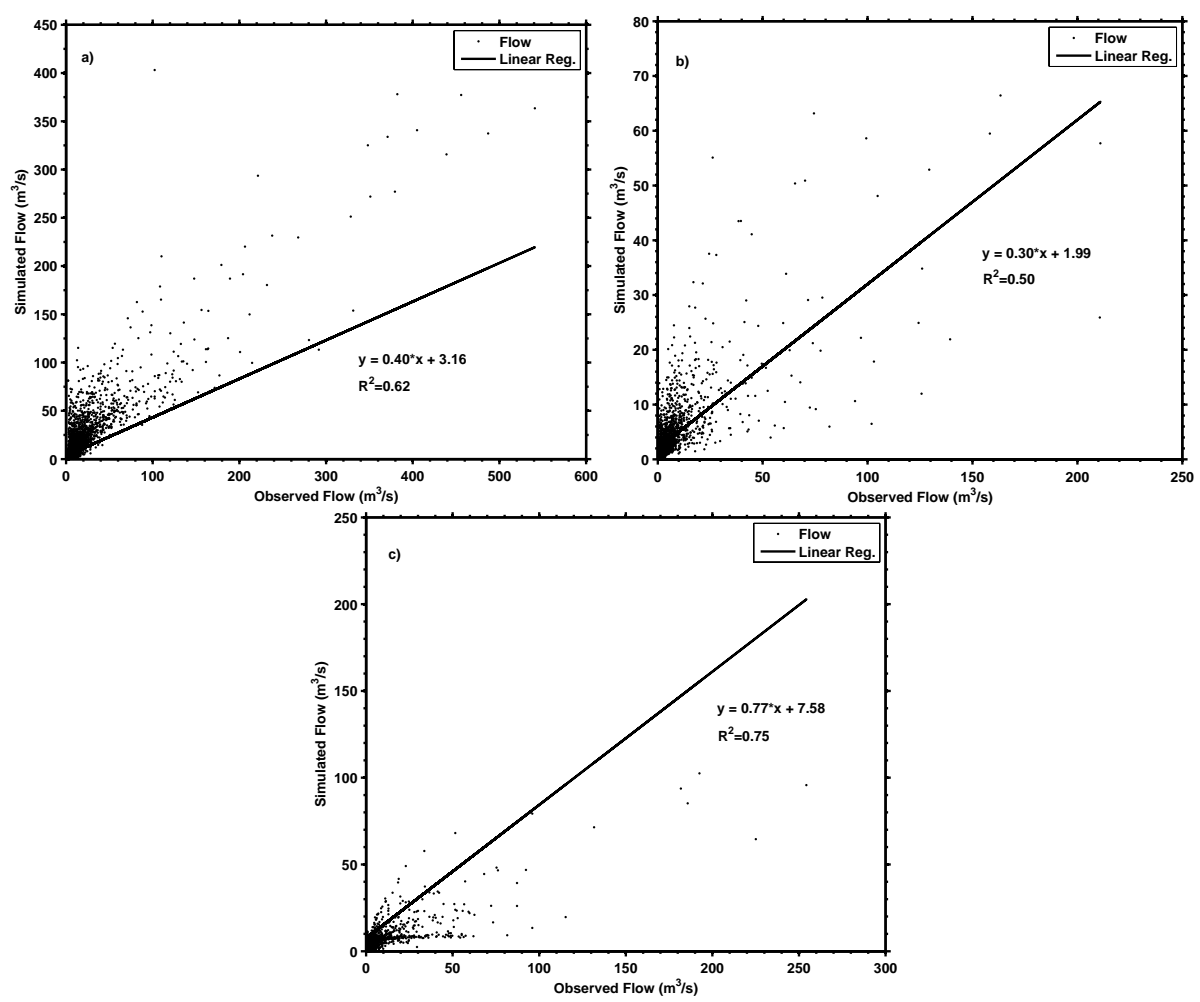

Fig. 5. Calibration for flow at three USGS gauge stations (a) 03333700, (b) 03333450 , and (c) 03335000 respectively.

\section{HESSD}

$5,1821-1862,2008$

\section{BMP optimization tool for pesticide control}

C. Maringanti et al.

Title Page

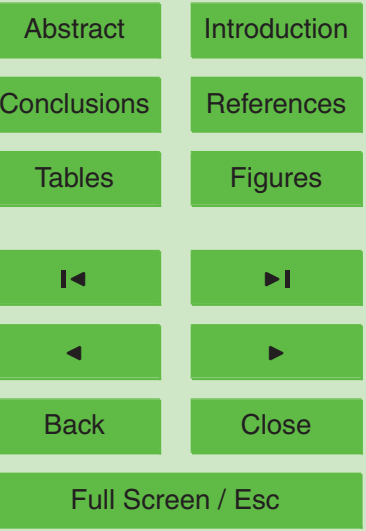

Printer-friendly Version

Interactive Discussion 


\section{HESSD}

5, 1821-1862, 2008

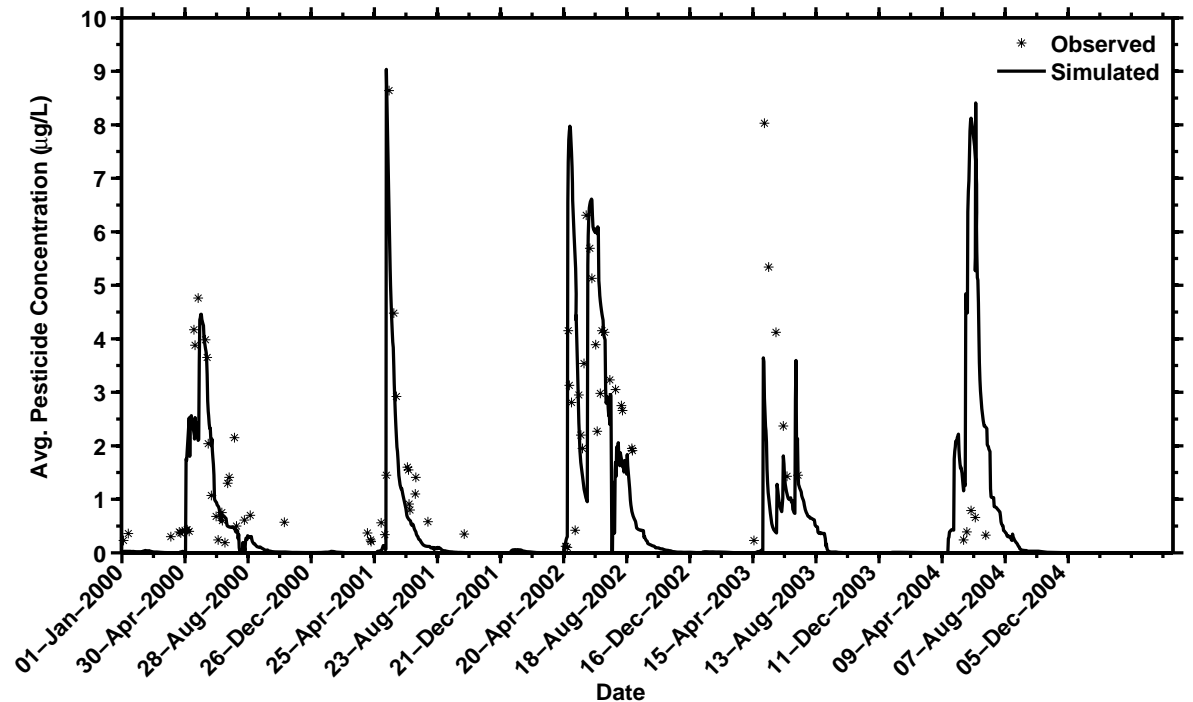

BMP optimization tool for pesticide control

C. Maringanti et al.

Title Page

Abstract

Introduction

Conclusions

References

Tables

Figures

14

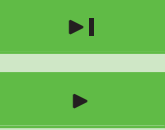

Back

Close

Full Screen / Esc

site \# 03911.

Printer-friendly Version

Interactive Discussion

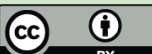




\section{HESSD}

$5,1821-1862,2008$

\section{BMP optimization tool for pesticide control}

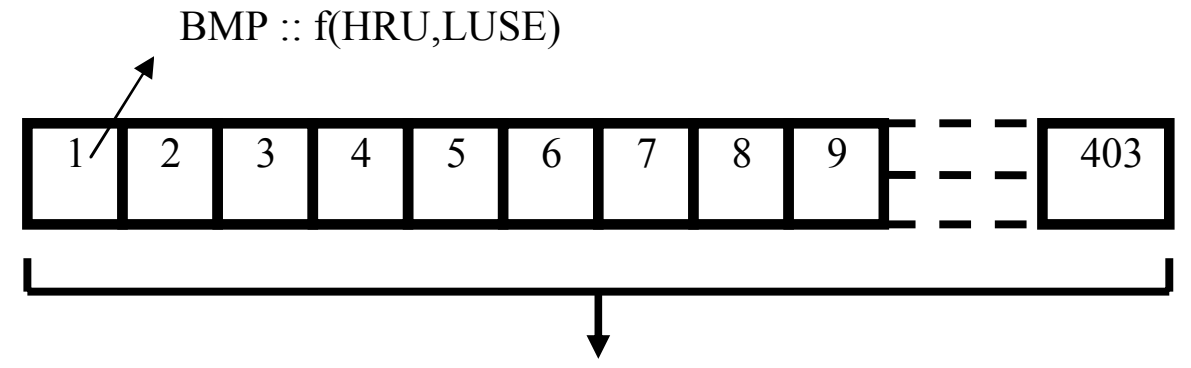

Chromosome

(Size: No. of HRUs)

Fig. 7. Gene string for BMP representation in a watershed.

C. Maringanti et al.

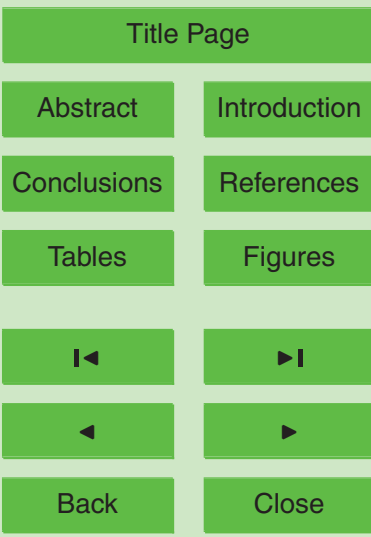

Full Screen / Esc

Printer-friendly Version

Interactive Discussion 


\section{HESSD}

5, 1821-1862, 2008
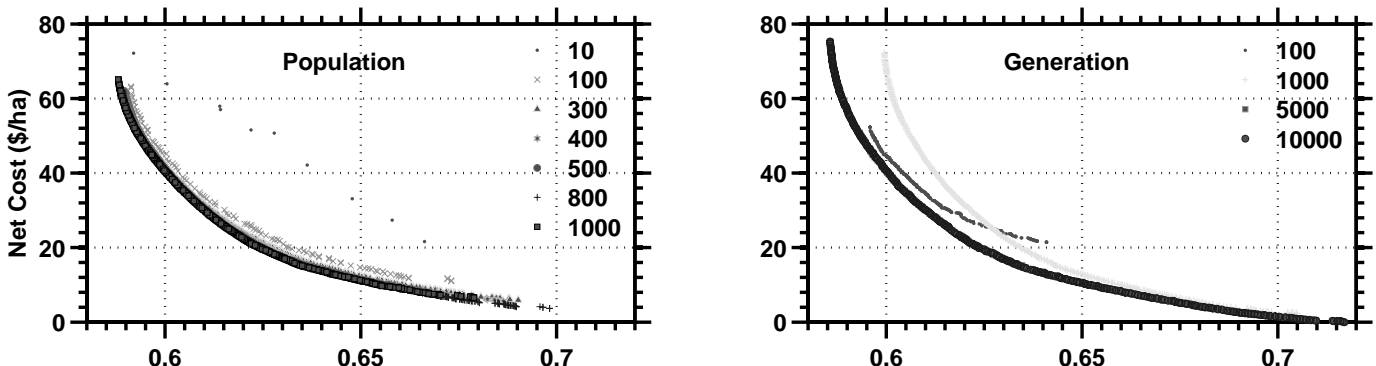

BMP optimization tool for pesticide control

C. Maringanti et al.
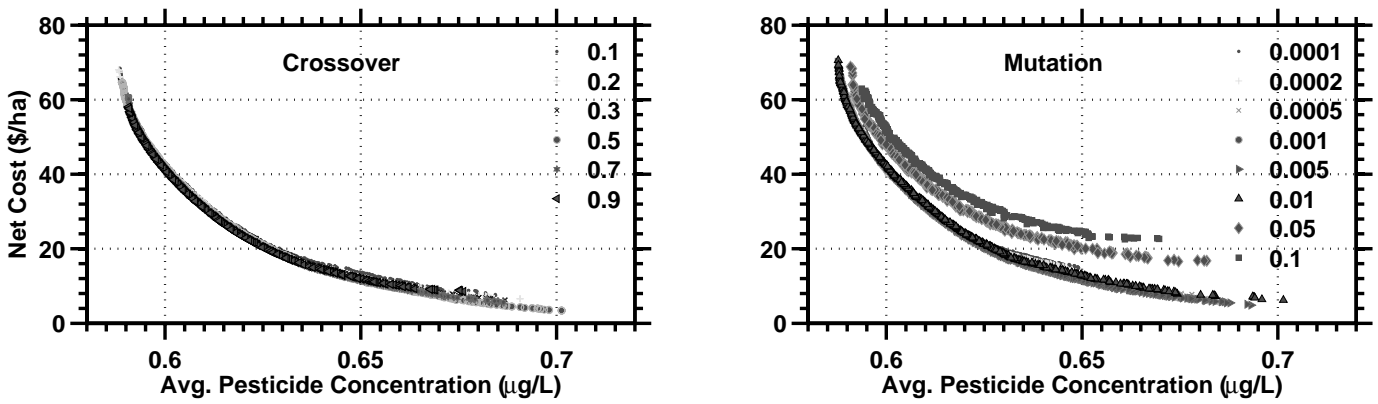

Title Page

Abstract

Introduction

Conclusions

References

Tables

Figures

14

$\rightarrow$

4

Back

Close

\section{Full Screen / Esc}

Printer-friendly Version

Interactive Discussion 


\section{HESSD}

5, 1821-1862, 2008

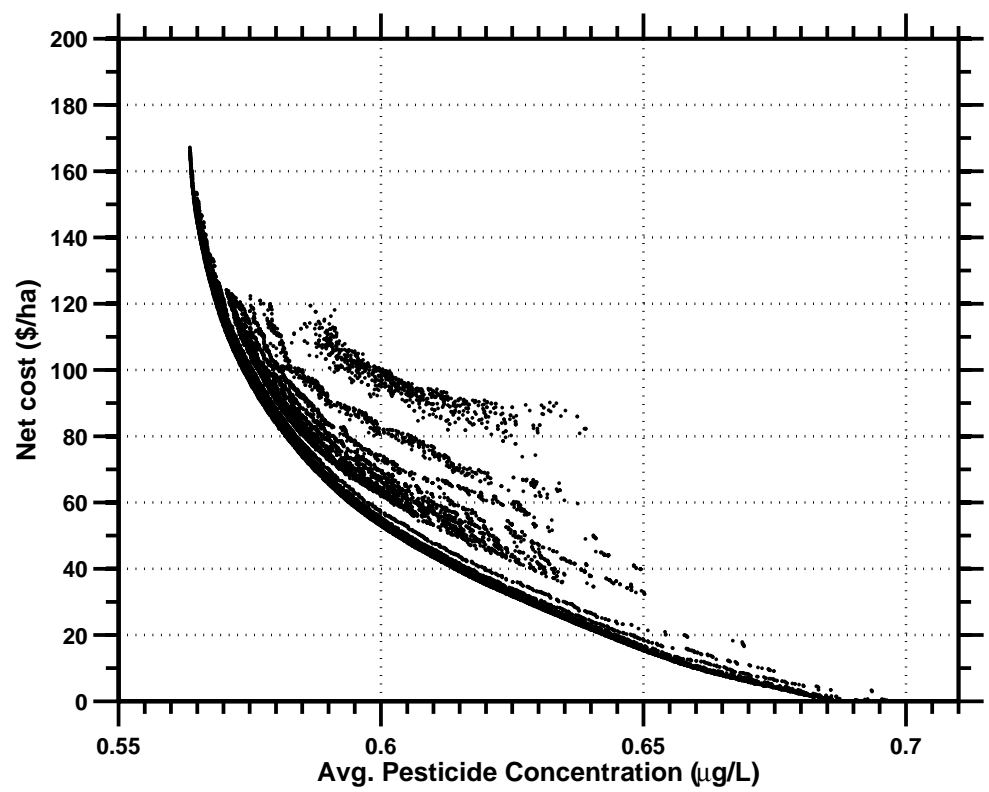

BMP optimization tool for pesticide control

C. Maringanti et al.

Title Page

Abstract

Introduction

Conclusions

References

Tables

Figures

14

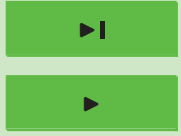

Back

Close

Full Screen / Esc

Printer-friendly Version

Interactive Discussion

cC) (i) 


\section{HESSD}

$5,1821-1862,2008$

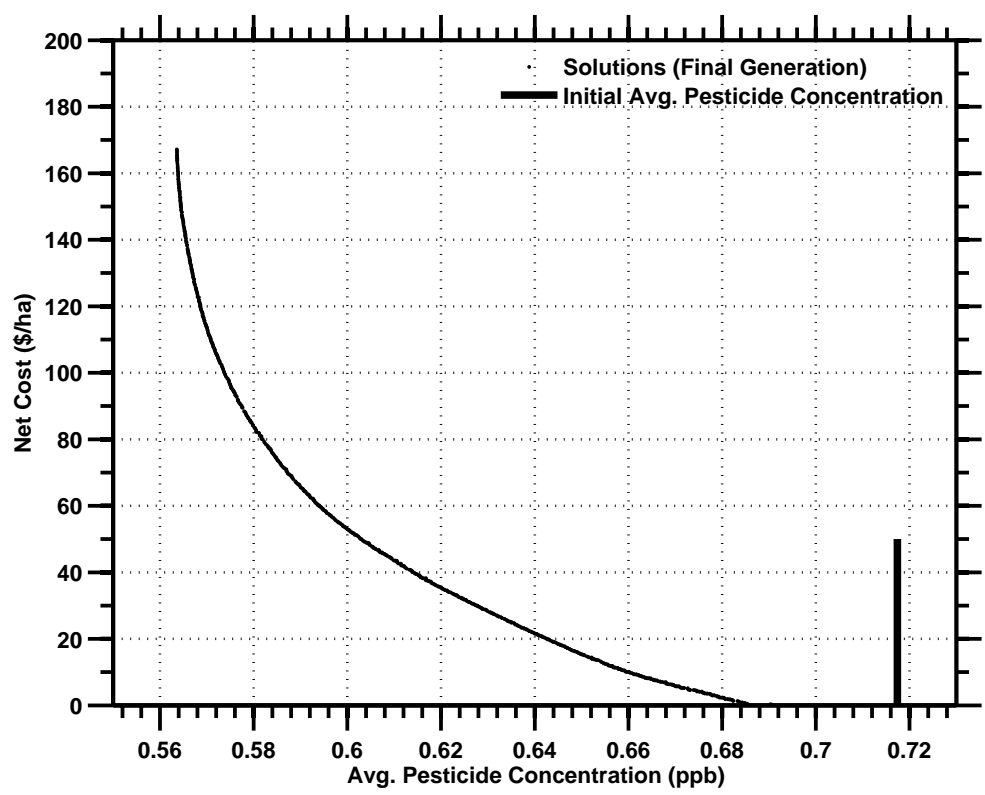

Fig. 10. Pareto-optimal front after the final generation of the pesticide model.

\section{BMP optimization tool for pesticide control \\ C. Maringanti et al.}

Title Page

Abstract

Introduction

Conclusions

References

Tables

Figures

I

4

Back

\section{Full Screen / Esc}

Printer-friendly Version

Interactive Discussion 
(a)
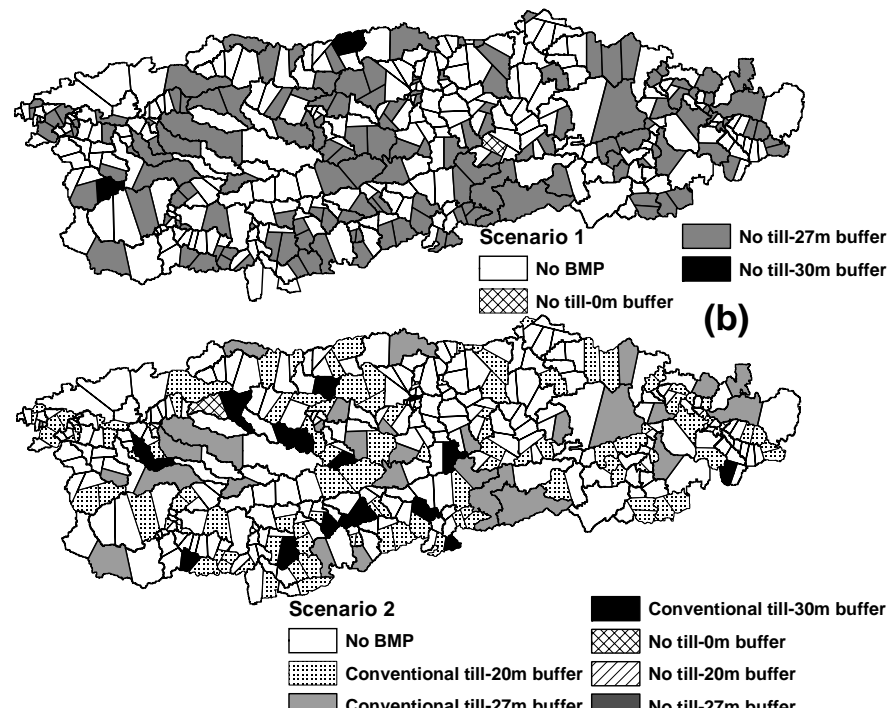

(c)

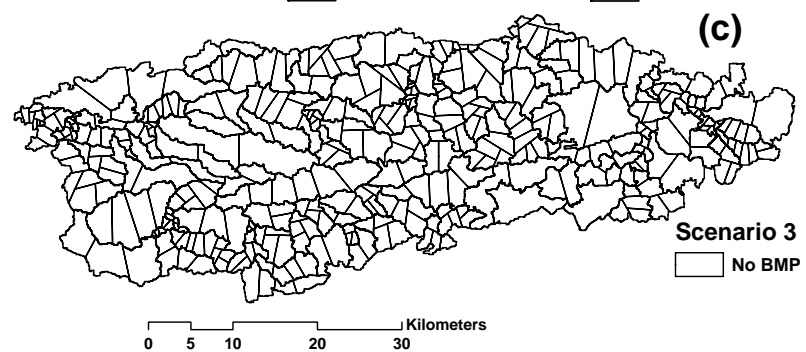

Fig. 11. Type and location of BMPs selected in Wildcat Creek Watershed for atrazine control.

\section{HESSD}

$5,1821-1862,2008$

BMP optimization tool for pesticide control

C. Maringanti et al.

Title Page

Abstract

Introduction

Conclusions

References

Tables

Figures

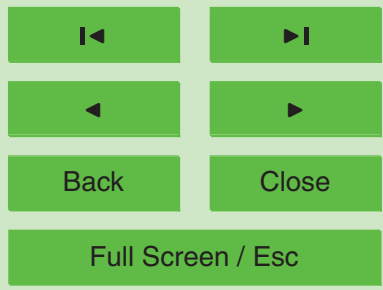

Printer-friendly Version

Interactive Discussion 